Article

\title{
The Views of Stakeholders on Mandatory or Voluntary Use of a Simplified Standard on Non-Financial Information for SMEs in the European Union
}

\author{
Paula Gomes dos Santos ${ }^{1,2}{ }^{\mathbb{D}}$, Fábio Albuquerque ${ }^{1}(\mathbb{D}$, Maria Albertina Barreiro Rodrigues $1,3, *$ (D) \\ and Ana Isabel Morais 4 (D)
}

1 ISCAL-Lisbon Accounting and Business School, Instituto Politécnico de Lisboa, 1069-035 Lisbon, Portugal; pasantos@iscal.ipl.pt (P.G.d.S.); fhalbuquerque@iscal.ipl.pt (F.A.)

2 COMEGI, Universidades Lusíada, 1300-001 Lisbon, Portugal

3 School of Business and Social Sciences, Universidade Europeia, 1500-210 Lisbon, Portugal

4 Advance/CSG, ISEG-Lisbon School of Economics \& Management, Universidade de Lisboa, 1200-781 Lisbon, Portugal; anamorais@iseg.ulisboa.pt

* Correspondence: mariabrodrigues@netcabo.pt

Citation: Santos, P.G.d.;

Albuquerque, F.; Rodrigues, M.A.B.;

Morais, A.I. The Views of

Stakeholders on Mandatory or

Voluntary Use of a Simplified

Standard on Non-Financial

Information for SMEs in the

European Union. Sustainability 2022,

14, 2816. https://doi.org/10.3390/

su14052816

Academic Editor: Lúcia

Lima Rodrigues

Received: 1 February 2022

Accepted: 23 February 2022

Published: 28 February 2022

Publisher's Note: MDPI stays neutral with regard to jurisdictional claims in published maps and institutional affiliations.

Copyright: () 2022 by the authors. Licensee MDPI, Basel, Switzerland. This article is an open access article distributed under the terms and conditions of the Creative Commons Attribution (CC BY) license (https:/ / creativecommons.org/licenses/by/ $4.0 /)$.

\begin{abstract}
This paper investigates the variables that may explain the views of stakeholders regarding the need for a simplified non-financial reporting (NFR) standard for small and medium-sized enterprises (SMEs) in the European Union (EU) and whether this standard should be mandatory or voluntary. This paper uses, as a source, 588 answers provided by different groups of stakeholders within the process of public consultation conducted by the EU, from February to June 2020, concerning possible revisions to the provisions of the Directive on NFR. The findings showed that the most consensual attribute that probably explains the views of stakeholders on this matter is the importance attributed by them to the concepts of comparability, reliability, and relevance. From the stakeholders' perspective, this topic may also be explained by the users' needs. Notwithstanding, its importance may differ, depending on the type of user. These findings are relevant within the process of developing an NFR model applicable to SMEs based on a mandatory standard, providing evidence that regulators and standard-setters should consider the qualitative characteristics of non-financial information as well as the needs of various stakeholders within this process.
\end{abstract}

Keywords: comparability; constraints; relevance; reliability; usefulness; users

\section{Introduction}

This section is divided into two subsections. The first presents a background on the topics related to this paper, namely the context of the discussion on the mandatory or voluntary use of a simplified non-financial standard for small and medium-sized enterprises (SMEs). The second one provides the literature review and the hypotheses.

\subsection{Background}

Non-financial information (NFI) is increasingly important and emerges as a key component of companies' communication and corporate reports [1] once it is a tool for companies to communicate a more transparent image and also for managers to measure development in non-financial areas [2]. Furthermore, the disclosure of additional and better sustainable, or non-financial, information may benefit capital markets through better liquidity, minor cost of capital, and greater capital allocation [3]. Disclosure of NFI is a way to improve the transparency and communication of entities' social and ethical practices. According to Brundtland [4] (p. 35), the concept of sustainable development concerns "development that meets the needs of the present without compromising the ability of future generations to meet their own needs". Focusing on the business level, corporate sustainability aims to 
meet the needs of entities' stakeholders without compromising the ability to meet future stakeholders' needs [5]. Therefore, there is the need to disclose information about how companies' activities impact the environment and society.

The Directive 2014/95/EU of the European Parliament and of the Council of 22 October 2014 [6], also known as the Non-Financial Reporting Directive (NFRD), required large Public-Interest Entities (PIEs) with more than 500 employees (i.e., large listed companies and large banks and insurance companies, whether listed or not) to provide a non-financial statement from 2018 onwards. Therefore, in the European Union (EU), the NFI disclosure has been particularly focused on larger companies, and SMEs have largely been left out from it until now. In 2020, the public consultation process of the NFRD brought not only the discussion around the need for increasing the requirements regarding NFI, but also the inclusion of SMEs in its scope [7].

In the context of the NFRD, the concept of SMEs follows the Directive 2013/34/EU. SMEs constitute the most dynamic sector of many economies. In the EU, and based on data for 2021 using the number of employees as the only criteria, it is estimated that SMEs comprise 22.6 million firms, representing more than $99 \%$ of the total, and a large part of Gross Domestic Product (GDP) and employment [8]. SMEs also constitute the majority of obligors of banks within the United States and across Europe [9].

The globalization of the economy increased competition and international exchanges, exposing SMEs to new international challenges. On the other hand, although SMEs individually do not exert great pressure on the environment, collectively they are responsible for up to $70 \%$ of the environmental impact or the industrial pollution in Europe [10,11].

Therefore, SMEs must disclose information about the environment and social matters, because evaluation models that use financial information may be improved with NFI and might be a useful tool for investors and banks [9]. Furthermore, considering that most of the companies in Europe are SMEs, it is relevant to assess the stakeholders' perspective on the recent interest in including them in the scope of NFI disclosure. Then, based on the legitimacy and stakeholder theories, this paper aims to assess the answers to the public consultation of the project of the revised Directive 2014/95/EU, in what concerns the variables that may explain the views of stakeholders regarding the need for a simplified non-financial reporting (NFR) standard for SMEs in the EU and whether this standard should be mandatory or voluntary.

Besides demographic characteristics of participants in this process of public consultation (respondents), the qualitative characteristics of information disclosed, such as relevance, comparability, and reliability, as well as the constraints and usefulness of providing this information to different users, were selected as possible explanatory factors. Further, the perspective of respondents regarding the key stakeholders' groups (users of NFI) that should also be involved in the process of developing a European standard on NFI was also an element taken into consideration within the analysis.

The findings showed that the most consensual attribute that probably explains the views of stakeholders on this matter is the importance attributed by them to the concepts of comparability, reliability, and relevance. Furthermore, users' needs regarding NFR may have different levels of attributed importance from the stakeholders' perspective.

The literature indicates that much remains to study regarding the NFRD and, in particular, the lack of agreement on voluntary versus mandatory NFR [12]. Furthermore, the revision of the Directive, with the inclusion of SMEs in its scope, introduced a new matter to the discussion. Therefore, this paper intends to fill this gap, having several contributions. First, it extends prior relevant literature by investigating the stakeholders' attributed importance to the several elements that should be considered in the process of issuing a NFR standard for SMEs in the EU, such as the ones included in this research. Second, our research contributes to an understanding of the stakeholders' perspective on the recent interest in including SMEs in the scope of NFR in the EU through a standardization process. Third, it covers the paths to achieve it and assesses, more specifically, the possible explanatory factors behind the acceptance of a mandatory simplified standard for SMEs 
from the stakeholders' perspective. Consequently, the findings may be useful for users, preparers, regulators, and standard-setters.

The paper is organized as follows. Section 1 presents a background and a review of the literature on NFR by SMEs in the EU. Section 2 sets forth the materials and methods. Section 3 presents the obtained results, being followed by the discussion. Finally, our conclusions, research limitations, and directions for future research are presented in Section 5 .

\subsection{Previous Research and Hypotheses}

Literature on financial reporting for SMEs is scarce. Notwithstanding, more development has been achieved in comparison with NFI.

Concerning financial reporting standards for SMEs, in particular, research is focused on the determinants of the IFRS for SMEs adoption $[13,14]$ and the stakeholders' perceptions about the costs and benefits of this standard [15-18]. Zahid and Simga-Mugan [19] found that common law countries, with lower regulatory efficiency, market openness, and economic growth are more likely to adopt IFRS for SMEs. Uyar and Güngörmüş [16] found that education level and experience (e.g., employees of BIG 4) play an important role in the knowledge about accounting standards. Litjens and Bissessur [14] analyzed the association of costs and benefits of adopting IFRS for SMEs and preparers' perceptions of those costs and benefits.

Regarding NFR for SMEs, previous literature covers, for instance, who contributes to the process, how participation varies, and which groups or claims succeed. Furthermore, it shows that SMEs have fewer incentives for disclosing NFI. However, evidence is still scarce [3] and fragmented [20]. This lack of research can be explained by the fact that non-financial disclosure is still voluntary for SMEs [21]. Furthermore, in comparison with larger ones, SMEs do not have the same means, in terms of the level of accounting expertise, computerized accounting systems [22], and financial resources. Then, this lack of means justified that the NFRD foresaw the burden for SMEs on disclosing NFI, which led to the need for a simplified standard for those entities.

The existence of a standard on NFR for SMEs, more specifically, raises the question of whether this standard should be mandatory or voluntary. Based on Christensen et al. [3], it can be assumed that a mandatory standard on NFI requires that firms report corporate social responsibility (CSR) activities, risks, and policies; identifies CSR topics relevant for certain industries and firms; identifies relevant metrics and its calculations; and, finally, describes where and how the information should be presented.

NFR disclosure has been mostly explained by the legitimacy and stakeholder theories $[23,24]$. Legitimacy theory emphasizes that business actions are subject to social acceptance. Based on that, entities will be more willing to report NFI to meet the stakeholders' social expectations, with the aim of legitimating their actions [23]. The legitimacy theory also explains why sustainability reporting is now becoming a "moral" reporting obligation [24]. Crossley, Elmagrhi, and Ntim [25] found that SMEs engage with a blend of symbolic and substantive sustainable practices to strengthen the legitimacy of their actions. Furthermore, Cho and Patten [26] stated that legitimacy theory proposes that companies facing greater exposure and with weaker environmental performance would be expected to disclose environmental information more widely and, therefore, use disclosure as a legitimizing instrument.

The legitimacy theory is also related to the stakeholder theory [27], which is especially helpful for justifying and interpreting the determinants for NFR development [24]. This latter assumes that companies have to be managed in the interest of all their stakeholders, not only in the interest of their shareholders [28]. In this sense, NFR becomes a way to meet the information requests of different stakeholder groups, being necessary to involve them to maintain a satisfactory dialogue that fulfills their needs [29]. Rossignoli, Stacchezzini, and Lai [30] concluded that the usefulness of voluntary nonfinancial disclosure depends on the 
institutional patterns and is higher when strong institutional enforcement and disclosure requirements exist.

The following subsubsections present the literature review and the related hypotheses that are behind the views of stakeholders on the mandatory use of a simplified standard on NFR for SMEs in the EU.

\subsubsection{Comparability}

Until now, the demand for NFI has been answered by the issue of voluntary reporting standards (e.g., Global Reporting Initiative). Previous papers have showed that the voluntary nature of the standards raised some questions in terms of lack of comparability $[3,19,31]$.

Under the functionalist perspective [17], the NFI can be measured and compared from rigorous and verified reports. The European Financial Reporting Advisory Group (EFRAG) [32] (p. 60) states that the purpose of sustainability reporting is to provide "relevant, faithful, comparable, and reliable information on (i) material sustainability impacts of the reporting entity on affected stakeholders (including the environment) and (ii) material sustainability risks and opportunities for its value creation, enabling users of information (i) to understand the reporting entity's sustainability objectives, position, and performance and (ii) to inform their decisions relating to their engagement with the entity". The comparability of sustainability information is evident when it is presented on a basis that is consistent over time and, to the greatest extent possible, in a way that enables comparisons between reporting entities.

However, previous studies show the lack of comparability between sustainability reports $[3,33,34]$. The causes of the non-comparability of NFI were investigated and included the lack of standardization and the plurality of reporting guidelines [35]; technical and noncompliance issues [17]; the use of different NFR standards [18]; the lack of materiality and completeness of NFR [36]; the managerial capture of the reporting process, which can promote impression management strategies [37-41]; and greenwashing [42].

The voluntary nature of NFR seems to contribute to the lack of cross-firm comparison [17]. The Directive 2014/95/EU only prescribes the minimum requirements for the NFR to be disclosed, without imposing specific disclosure rules [43]. Additionally, the Directive also gives the Member States some flexibility in its transposition and enforcement. Overall, the Directive does not contribute decisively to increasing the comparability of NFR [44-46], increasing the risk of greenwashing [47].

One of the most effective ways to achieve comparable information is through a normalization process (reporting based on standards). EFRAG [32] states that overall comparability is only possible when standards require mandatory requirements for all reporting entities. Based on previous research, we predict that stakeholders tend to consider that standards on NFR should be mandatory whenever they have the perception that the lack of comparability of NFR is a significant problem. Therefore, these entities tend to view the mandatory standards as an efficient mechanism to reduce the lack of comparability. These arguments lead to the following hypothesis:

Hypothesis 1 (H1). There is a positive association between the perception about the lack of comparability of NFI disclosed being a significant problem and the opinion that the simplified standard for SMEs should be mandatory.

\subsubsection{Reliability}

As stated by EFRAG [32], NFR should be not only comparable but also reliable, i.e., NFR should enable users to rely on the information to make their decisions. Previous studies have shown that the adoption of GRI indicators has a positive effect on the reliability of NFR [29,48], but NFR is still considered more as a social legitimation instrument [26,49-51] than a reliable information source. In addition, the content of current sustainability reports often is incomplete and selective $[35,36]$. 
One way to enhance the reliability of NFR would be to mandate the adoption of a common set of NFR standards. The use of these standards would also allow the assurance and enforcement of NFR.

Based on previous research, we predict that stakeholders tend to consider that standards on NFR should be mandatory whenever they have the perception that the limited reliability of NFR is a significant problem. These entities tend to view the mandatory standards as an efficient mechanism to increase reliability, not only because those standards may include more clear disclosure principles and/or rules, but they can also facilitate the assurance of NFI. These arguments lead to the following hypothesis:

Hypothesis 2 (H2). There is a positive association between the perception about the limited reliability of NFI disclosed being a significant problem and the opinion that the simplified standard for SMEs should be mandatory.

\subsubsection{Relevance}

NFI is relevant when it can influence the users' decision-making, both from the perspective of material impacts on society and the environment and from the perspective of financial impacts. Traditionally, value relevance studies focus on the price/returns-earnings relation by using different financial variables. More recently, several studies analyzed the value relevance of NFR with inconclusive findings. Some studies showed that NFI has a positive effect on market value [52-55], while others provided evidence of a negative effect on share prices [56-58].

For contexts where NFI is mandatory, Tang and Zhong [59] found that after mandatory sustainability reporting regulation is enacted, companies face a lower possibility of a shares' price decrease. In South Africa, the disclosures in Integrated Reports seem to have a positive effect on firm valuation [60]. Krueger et al. [61] also found that mandatory environmental, social, and governance (ESG) reporting has a positive effect on analysts' forecasts since they become more accurate and less dispersed.

Based on previous research and considering that mandatory NFI is important to increase the relevance of NFI and reduce information asymmetry, we predict that stakeholders tend to consider that standards on NFI should be mandatory whenever they have the perception that entities do not disclose all relevant NFI. These arguments lead to the third hypothesis:

Hypothesis $3 \mathbf{~ ( H 3 ) . ~ T h e r e ~ i s ~ a ~ p o s i t i v e ~ a s s o c i a t i o n ~ b e t w e e n ~ t h e ~ p e r c e p t i o n ~ t h a t ~ e n t i t i e s ~ d o ~ n o t ~}$ disclose all relevant NFI and the opinion that the simplified standard for SMEs should be mandatory.

\subsubsection{Usefulness}

Previous studies have shown a positive relationship between financial performance and the company's sustainable behaviour [1]. Therefore, NFI is useful, since it represents a facilitating factor for SMEs to access financial resources and might enable companies to accomplish and maintain a competitive advantage [20].

A mandatory NFR may change the firm's behaviour since it has effects on capital markets and the potential to improve information to several stakeholders [3]. From the management perspective, NFI commitment and compliance is also useful, since it enables SMEs to prevent sanctions, legal restrictions, and accusations from pressure groups and human rights activists. Furthermore, a crucial element for the usefulness of NFI disclosure is stated as being the independent verification of information by the increase in the reliability and comparability of the information [62].

It has also been noted in previous literature that, bearing in mind that the objective of NFI is to lead to a change in firm behaviour through NFR, wider and normative factors, such as societal, political, and moral factors, are more appropriate in the setting of NFI standards. In a complementary perspective, those standards should be also focused on usefulness, considering its informative purpose. Additionally, the type of relationship 
between entities and their stakeholders, which can be the users of NFR, may affect the usefulness of an NFI standard. Then, in a more passive interaction between entities and their stakeholders, an NFI standard is more likely to be useful for a more rigid NFR. Conversely, a more customized NFR may arise in a context of a more relational interaction between entities and their stakeholders, with less need for a standard [3].

Based on previous research and considering that mandatory NFI is important to increase the usefulness of NFI disclosure, we predict that stakeholders tend to consider that standards on NFI should be mandatory whenever they have the perception that entities do not disclose all useful NFI. These arguments lead to the fourth hypothesis:

Hypothesis 4 (H4). There is a positive association between the perception that the existence of a simplified NFR standard for SMEs is useful and the opinion that the simplified NFR standard for SMEs should be mandatory.

\subsubsection{Constraints}

Some authors noted that efficient compliance requires a system for NFI information that can be costly, especially for smaller firms. It has also been mentioned that the increase of non-material disclosures may compel higher treating costs, enhance the complexity, and diminish the usefulness of the report [3]. The complexity of sustainability standards, most of the time developed facing large company's needs, are identified as an obstacle for SMEs [63], and the importance of proportionality has been stated [64]. Furthermore, the characteristics of SMEs requires specific NFR standards [45] to avoid that complying with them would be too costly [3].

The lack of resources has been identified as one of the main barriers to the implementation of sustainable management by SMEs, and a proposal for the development of low-cost tools in this field that could facilitate both decision making and monitoring has been made [65]. The lack of resources compelled SMEs to disclose the simplest possible reporting, on the limit, to comply with the required minimums [21,66].

Nevertheless, some studies suggest that the lack of resources is not the deterministic factor for implementing a proactive sustainability report in SMEs [67] and that the communication of a transparent image, legitimacy, and reputation is the most important reason for SMEs when engaging in the NFI disclosure $[2,68]$.

Considering that NFR requests focus on large companies, they may be not appropriate to SMEs, particularly those with limited resources; therefore, particular consideration on how to include SMEs in the NFR landscape appears to be missing [32].

Based on previous research and considering that mandatory NFI is important to decrease the limitations of NFI disclosure, we predict that stakeholders tend to consider that standards on NFI should be mandatory whenever they have the perception that entities' NFI disclosure increases the burden of the report. These arguments lead to the fifth hypothesis:

Hypothesis 5 (H5). There is a positive association between the perception that the existence of a simplified NFR standard for SMEs would reduce the burden for SMEs and the opinion that the simplified standard for SMEs should be mandatory.

\subsubsection{Users}

In the EU, the national legislation's requirements have a large significance on the disclosure of NFI by SMEs. Additionally, many SMEs are increasingly disclosing NFI, possibly due to the pressure of different stakeholders, such as other companies with which they have trade relationships, as well as capital providers $[2,69,70]$. Being pressured by other businesses, larger SMEs have also begun pressuring their supply chain partners, mainly if they are large companies' suppliers [65].

Through their loaning activities, capital providers play an important role in the sustainable development process. Furthermore, to assess and manage SMEs' credit risk, 
capital providers need to develop and employ procedures and models adapted to the SMEs' singularities and specific needs [71].

For NFI to produce impact, the users (diverse stakeholders) need to be conscious of it. Voluntary NFI disclosures are not necessarily reliable; therefore, companies may not gain from all desirable benefits. On the opposite hand, if the standards are well implemented, a mandatory standard may provide reliable commitment [3].

Based on previous research and considering that mandatory NFI is important to increase the use of NFI disclosure by users, we predict that stakeholders tend to consider that standards on NFI should be mandatory whenever they have the perception that entities NFI disclosure is useful to users. These arguments lead to the sixth hypothesis:

Hypothesis 6 (H6): There may be an association, depending on the type of user, between the expected usefulness of NFR by SMEs and the opinion that the simplified standard for SMEs should be mandatory.

\section{Materials and Methods}

This section aims to present a previous description of data gathered from the survey that will be subsequently used in logistic regression models detailed in the next section. The logistic regression, as a method that estimates the probability of occurrence of an event, was used to determine the predictive variables that explain the stakeholders' views on the mandatory or voluntary use of a simplified standard on NFI for SMEs.

Previously, the next section will also present more in-depth descriptive statistics, as well as chi-square tests. The aim behind the analysis was to assess differences between subgroups identified from the demographic variables as well as other independent variables chosen from the previous literature review. In this latter case, six hypotheses were then proposed.

This paper used, as a source, the answers provided by different groups of stakeholders within the process of public consultation conducted by the EU, from February to June 2020, concerning possible revisions to the provisions of the NFRD. The original dataset used for this research includes, besides demographic variables, the answers provided to 45 questions, some of them with several sub-questions. This section presents only the content and characteristics of the questions used for this research. Notwithstanding, the complete dataset used can be found through the following link: https:/ /ec.europa.eu/info/law/better-regulation/have-yoursay/initiatives/12129-Revision-of-Non-Financial-Reporting-Directive/public-consultation_pt (Accessed 15 December 2021).

Participants from several countries, as representatives of entities of different sizes and sectors and within or out the scope of the provisions of the NFRD, provided their views on the questions launched by the $\mathrm{EU}$ on this theme. At the end of the process, 588 answers were gathered. Users were able to insert the option "I don't know/I don't have an opinion/not relevant" in some cases. Further, missing answers were also possible to most questions. However, those cases, when considered together, were frequently residual.

Finally, the database publicly available has no information for some demographic variables, such as type of users, respondent name, organization name, and country, to ensure the confidentiality criteria according to a previous request by respondents, which comprise almost $30 \%$ of all cases. Table 1 presents a brief characterization of the sample used, considering only the valid and specified answers. 
Table 1. Sample characteristics.

\begin{tabular}{lr}
\hline EU & In \% \\
\hline Yes & 81 \\
\hline No & 19 \\
\hline SMEs & In \% \\
\hline Yes & 28 \\
\hline No & 72 \\
\hline Capital Providers & In \% \\
\hline Yes & 18 \\
\hline No & 82 \\
\hline Scope & In \% \\
\hline Yes & 47 \\
\hline No & 53 \\
\hline User or Preparer of NFI & In \% \\
\hline User & 25 \\
\hline Preparer & 24 \\
\hline Both (a preparer and a user) & 35 \\
\hline Neither (a preparer nor a user) & 16 \\
\hline Type of Users & In \% \\
\hline Companies/business organizations & 27 \\
\hline Business associations & 25 \\
\hline NGOs (Non-governmental organizations) & 17 \\
\hline Public authorities & 7 \\
\hline Academics/Research Institutions & 5 \\
\hline Others & 18 \\
\hline & \\
\hline
\end{tabular}

It can be seen from Table 1 that the respondents were mostly from EU countries (81\%), which is certainly explained by the scope of the NFRD. All EU countries were represented, except Croatia, Estonia, Hungary, Latvia, and Slovenia. Consequently, answers from 22 out of 27 countries representative of the EU were gathered. Germany (18\%), Belgium (18\%), France $(10 \%)$, Spain $(7 \%)$, the Netherlands $(6 \%)$, and Italy $(6 \%)$ represented, however, almost two-thirds of the answers from the EU countries. Countries other than the EU included seven cases, namely the United Kingdom, United States, Switzerland, Norway, Canada, Japan, and Georgia. Notwithstanding, the United Kingdom and the United States comprised almost $80 \%$ of the answers from this set of countries.

By size, it may be highlighted that $28 \%$ of those respondents were or represented entities that are SMEs.

Answers for the question "field of activity or sector" were grouped into two groups: capital providers, comprising $18 \%$ of respondents, and entities other than those, as the remaining category $(82 \%)$. Entities that can play a role as capital providers included, for this purpose, investment, and investment management (e.g., hedge funds, private equity funds, venture capital funds, money market funds, securities), pension provision, banking, and insurance.

In the set of demographic variables, entities were also asked to answer if they are in the scope of NFRD, and $47 \%$ of the responses indicated inclusion in this case.

Following this, only $16 \%$ of those answers were provided by respondents who are neither a preparer nor a user of NFI.

Finally, the classification by type of users was mostly comprised of companies or business organizations $(27 \%)$, business associations $(25 \%)$, NGOs $(17 \%)$, public authorities $(7 \%)$, and academics or research institutions (7\%). Other users (18\%) included heterogeneous groups such as trade unions, citizens, and environmental and consumer organizations.

To accomplish the objective proposed for this paper, the analysis was focused on the answers to the following question 15: "If the EU were to develop a simplified standard 
for SMEs, do you think that the use of such a simplified standard by SMEs should be mandatory or voluntary?". These answers comprised the dependent variable.

As previously mentioned, this study also made use of the specific questions proposed by the EU in the survey as independent variables. From the set of existing questions, the ones that were particularly related to the six hypotheses proposed in the literature review were selected.

First, the questions related to the issues on qualitative characteristics, such as comparability, reliability, and relevance, were selected from questions 1.1, 1.2, and 1.3, which intended to understand the view of respondents on the extent to which they agree or disagree with the following statements about possible problems concerning NFR:

1. Question 1.1: "The lack of comparability of NFI reported by companies pursuant to the NFRD is a significant problem."

2. Question 1.2: "The limited reliability of NFI reported by companies pursuant to the NFRD is a significant problem."

3. Question 1.3: "Companies' reporting pursuant to the NFRD does not disclose all relevant NFI needed by different user groups."

Following this, the usefulness of a simplified standard for SMEs as well as the effectiveness of it as a means of limiting the burden on SMEs (constraints) were assessed from the answers provided to questions 13 and 14, as follows:

1. Question 13: In your opinion, would it be useful for there to be a simplified standard and/or reporting format for SMEs?

2. Question 14: To what extent do you think that a simplified standard for SMEs would be an effective means of limiting the burden on SMEs arising from information demands they may receive from other companies, including financial institutions?

Finally, the perspective of respondents regarding the key stakeholders' groups (users of NFI) that should also be involved in the process of developing a European standard on NFI was extracted from questions 17 and 18. The following stakeholders' groups were assessed from those two questions: investors, preparers, accountants (including auditors), civil society representatives (CSRs) and NGOs, academics, and others.

Questions 13,15, and 18 (in this latter case, only regarding the remaining stakeholders group comprised by "others") represented the variables with the characteristic of a dichotomic variable, as the answers provided assumed the main options of "yes" or "no".

Thus, it is worthwhile to mention that all other questions, which intended to understand to what extent respondents agreed or disagreed with a given statement, had a characteristic of a four-item Likert scale, beginning with "not at all" and finishing with "to a very great extent", passing through "to some extent but not much" and "to a reasonable extent". To make these answers easily comparable with the remaining independent variables, as well as with the dependent variable extracted from question 15, the answers "not at all" and "to some extent but not much", on one hand, and "to a reasonable extent" and "to a very great extent", on the other hand, were also gathered and transformed into a dichotomic variable.

To sum up, the questions 1.1 to $1.3,14,17$, and 18 (except for the group comprised by "others") were transformed. In doing that, it was possible to perform the analysis using contingency tables and the non-parametric chi-square test, which requires two non-related answers as samples and dichotomic variables.

\section{Results}

This section is divided into two subsections. The first presents a descriptive analysis and the results from the chi-square test to a previous overview of the answers on the mandatory use of a simplified standard for SMEs with a breakdown by each independent variable proposed. The second one provides the logistic regression performed to a multivariate analysis of data gathered. 


\subsection{Descriptive Analysis and Chi-Square Test}

Table 2 presents a descriptive analysis of the groups previously mentioned, through a cross-reference table, considering their opinion on the introduction of a simplified, but mandatory, standard on NFI for SMEs. Furthermore, a chi-square test was performed to check if there were significant differences between the opinions of the subgroups under analysis regarding this question.

Table 2. Descriptive statistics and chi-square tests for demographic variables.

\begin{tabular}{|c|c|c|c|c|c|c|c|c|c|}
\hline & & \multicolumn{7}{|c|}{ Mandatory } & \multirow{3}{*}{$\begin{array}{l}\text { Chi-Square } \\
(p \text {-Value })\end{array}$} \\
\hline & & \multicolumn{4}{|c|}{ Number } & \multicolumn{3}{|c|}{ Percentage } & \\
\hline & & No & Yes & Other * & Total & No & Yes & Other * & \\
\hline \multirow{3}{*}{$\mathrm{EU}$} & No & 25 & 32 & 21 & 78 & 32 & 41 & 27 & \multirow{3}{*}{0.965} \\
\hline & Yes & 129 & 163 & 45 & 337 & 38 & 48 & 13 & \\
\hline & Other* & 76 & 75 & 22 & 173 & 44 & 43 & 13 & \\
\hline \multirow{3}{*}{ SMEs } & No & 110 & 166 & 65 & 341 & 32 & 49 & 19 & \multirow{3}{*}{0.000} \\
\hline & Yes & 84 & 35 & 12 & 131 & 64 & 27 & 9 & \\
\hline & Other* & 36 & 69 & 11 & 116 & 31 & 59 & 9 & \\
\hline \multirow{2}{*}{$\begin{array}{l}\text { Capital } \\
\text { providers ** }\end{array}$} & No & 192 & 209 & 79 & 480 & 40 & 44 & 16 & \multirow{2}{*}{0.090} \\
\hline & Yes & 38 & 61 & 9 & 108 & 35 & 56 & 8 & \\
\hline \multirow{9}{*}{ Scope } & No & 86 & 131 & 31 & 248 & 35 & 53 & 13 & \multirow{3}{*}{0.001} \\
\hline & Yes & 100 & 76 & 41 & 217 & 46 & 35 & 19 & \\
\hline & Other * & 44 & 63 & 16 & 123 & 36 & 51 & 13 & \\
\hline & & \multirow{2}{*}{\multicolumn{8}{|c|}{$\begin{array}{l}\text { * These figures intend to provide information on the relevance of missing values, as well as the option "I don't } \\
\text { know /I don't have an opinion/not relevant" being jointly considered; ** Different from the other questions, it } \\
\text { was assumed, given the nature of this demographic question, that the subgroup "no" should include all answers } \\
\text { from respondents other than capital providers, including "other" and "not applicable", as there were no missing } \\
\text { values for this question. } \\
\text { Following this, Tables } 3 \text { and } 4 \text { present a similar analysis using the remaining questions } \\
\text { proposed as independent variables. }\end{array}$}} \\
\hline & & & & & & & & & \\
\hline & & \multicolumn{8}{|c|}{$\begin{array}{l}\text { Table 3. Descriptive statistics and chi-square tests for specific questions (other than by the stakehold- } \\
\text { ers' group). }\end{array}$} \\
\hline & & \multicolumn{7}{|c|}{ Mandatory } & \multirow{3}{*}{$\begin{array}{l}\text { Chi-Square } \\
(p \text {-Value })\end{array}$} \\
\hline & & & & per & & & rcents & & \\
\hline & & No & Yes & Other * & Total & No & Yes & Other* & \\
\hline \multirow{3}{*}{ Comparability } & No & 41 & 8 & 14 & 63 & 65 & 13 & 22 & \multirow{3}{*}{0.000} \\
\hline & Yes & 139 & 239 & 40 & 418 & 33 & 57 & 10 & \\
\hline & Other * & 50 & 23 & 34 & 107 & 47 & 21 & 32 & \\
\hline \multirow{3}{*}{ Reliability } & No & 63 & 15 & 24 & 102 & 62 & 15 & 24 & \multirow{3}{*}{0.000} \\
\hline & Yes & 108 & 213 & 31 & 352 & 31 & 61 & 9 & \\
\hline & Other * & 59 & 42 & 33 & 134 & 44 & 31 & 25 & \\
\hline
\end{tabular}


Table 3. Cont.

\begin{tabular}{|c|c|c|c|c|c|c|c|c|c|}
\hline & & \multicolumn{7}{|c|}{ Mandatory } & \multirow{3}{*}{$\begin{array}{c}\text { Chi-Square } \\
\text { ( } p \text {-Value) }\end{array}$} \\
\hline & & \multicolumn{4}{|c|}{ Number } & \multicolumn{3}{|c|}{ Percentage } & \\
\hline & & No & Yes & Other * & Total & No & Yes & Other * & \\
\hline \multirow{3}{*}{ Relevance } & No & 57 & 13 & 24 & 94 & 61 & 14 & 26 & \multirow{3}{*}{0.000} \\
\hline & Yes & 98 & 211 & 29 & 338 & 29 & 62 & 9 & \\
\hline & Other * & 75 & 46 & 35 & 156 & 48 & 29 & 22 & \\
\hline \multirow{3}{*}{ Usefulness } & No & 32 & 19 & 5 & 56 & 57 & 34 & 9 & \multirow{3}{*}{0.012} \\
\hline & Yes & 182 & 231 & 16 & 429 & 42 & 54 & 4 & \\
\hline & Other * & 16 & 20 & 67 & 103 & 16 & 19 & 65 & \\
\hline \multirow{3}{*}{ Constraints } & No & 65 & 51 & 9 & 125 & 52 & 41 & 7 & \multirow{3}{*}{0.011} \\
\hline & Yes & 152 & 206 & 8 & 366 & 42 & 56 & 2 & \\
\hline & Other* & 13 & 13 & 71 & 97 & 13 & 13 & 73 & \\
\hline
\end{tabular}

* These figures intend to provide information on the relevance of missing values, as well as the option "I don't know/I don't have an opinion/not relevant" being considered together.

Table 4. Descriptive statistics and chi-square tests for specific questions (by the stakeholders' group).

\begin{tabular}{|c|c|c|c|c|c|c|c|c|c|}
\hline & & \multicolumn{7}{|c|}{ Mandatory } & \multirow{3}{*}{$\begin{array}{c}\text { Chi-Square } \\
\text { ( } p \text {-Value) }\end{array}$} \\
\hline & & \multicolumn{4}{|c|}{ Number } & \multicolumn{3}{|c|}{ Percentage } & \\
\hline & & No & Yes & Other* & Total & No & Yes & Other * & \\
\hline \multirow{3}{*}{ Investors } & No & 82 & 81 & 25 & 188 & 44 & 43 & 13 & \multirow{3}{*}{0.447} \\
\hline & Yes & 132 & 185 & 39 & 356 & 37 & 52 & 11 & \\
\hline & Other * & 16 & 4 & 24 & 44 & 36 & 9 & 55 & \\
\hline \multirow{3}{*}{ Preparers } & No & 39 & 86 & 10 & 135 & 29 & 64 & 7 & \multirow{3}{*}{0.147} \\
\hline & Yes & 177 & 179 & 51 & 407 & 43 & 44 & 13 & \\
\hline & Other * & 14 & 5 & 27 & 46 & 30 & 11 & 59 & \\
\hline \multirow{3}{*}{ Accountants } & No & 128 & 154 & 45 & 327 & 39 & 47 & 14 & \multirow{3}{*}{0.903} \\
\hline & Yes & 85 & 112 & 17 & 214 & 40 & 52 & 8 & \\
\hline & Other * & 17 & 4 & 26 & 47 & 36 & 9 & 55 & \\
\hline \multirow{3}{*}{ CSRs/NGOs } & No & 173 & 138 & 44 & 355 & 49 & 39 & 12 & \multirow{3}{*}{0.000} \\
\hline & Yes & 40 & 128 & 17 & 185 & 22 & 69 & 9 & \\
\hline & Other* & 17 & 4 & 27 & 48 & 35 & 8 & 56 & \\
\hline \multirow{3}{*}{ Academics } & No & 162 & 178 & 47 & 387 & 42 & 46 & 12 & \multirow{3}{*}{0.002} \\
\hline & Yes & 44 & 84 & 11 & 139 & 32 & 60 & 8 & \\
\hline & Other * & 24 & 8 & 30 & 62 & 39 & 13 & 48 & \\
\hline \multirow{3}{*}{ Others } & No & 40 & 48 & 13 & 101 & 40 & 48 & 13 & \multirow{3}{*}{0.688} \\
\hline & Yes & 130 & 172 & 37 & 339 & 38 & 51 & 11 & \\
\hline & Other* & 60 & 50 & 38 & 148 & 41 & 34 & 26 & \\
\hline
\end{tabular}

* These figures intend to provide information on the relevance of missing values, as well as the option "I don't know/I don't have an opinion/not relevant" being considered together.

Table 3 provides the information regarding the qualitative characteristics of comparability, reliability, and relevance, as well as the issues related to the usefulness and constraints matters discussed in this paper. 
Following this, Table 4 provides the data by the stakeholders' group.

The next subsection aims to present the logistic regression models proposed.

\subsection{Regression Analysis}

The first set of models only includes, as independent variables, the specific questions that were covered by the literature review. Next, the subsequent set of models will include the demographic variables as control variables to assess the robustness of the results.

Before performing the regression analysis, a correlation matrix was performed for all independent variables that were proposed to be used in this research, to previously assess if there was any multicollinearity problem. A very high correlation $(r \geq 0.9)$ was observed between reliability and relevance. Despite that, no significant correlation was found regarding the variable comparability. However, after assessing the variation index factor (VIF), as an additional procedure suggested, for instance, by Midi et al. [72] and Senaviratna and Cooray [73], for those three variables, a high value for VIF, despite lower for the latter, was observed.

Then, the first three logistic regression models performed for this research are given as follows:

$$
\begin{aligned}
\operatorname{Logit}\left(A_{i}\right)= & \beta_{1} \text { Comparability }+\beta_{2} \text { Usefulness }+\beta_{3} \text { Effectiveness }+\beta_{4} \text { Investors }+\beta_{5} \text { Preparers } \\
& +\beta_{6} \text { Accountants }+\beta_{7} \text { CSRs } / N G O s+\beta_{8} \text { Academics }+\beta_{9} \text { Others }+\varepsilon \\
\operatorname{Logit}\left(A_{i}\right)= & \beta_{1} \text { Reliability }+\beta_{2} \text { Usefulness }+\beta_{3} \text { Effectiveness }+\beta_{4} \text { Investors }+\beta_{5} \text { Preparers } \\
& +\beta_{6} \text { Accountants }+\beta_{7} \text { CSRs } / N G O s+\beta_{8} \text { Academics }+\beta_{9} \text { Others }+\varepsilon \\
\operatorname{Logit}\left(A_{i}\right)= & \beta_{1} \text { Relevance }+\beta_{2} \text { Usefulness }+\beta_{3} \text { Effectiveness }+\beta_{4} \text { Investors }+\beta_{5} \text { Preparers } \\
& +\beta_{6} \text { Accountants }+\beta_{7} \text { CSRs } / N G O s+\beta_{8} \text { Academics }+\beta_{9} \text { Others }+\varepsilon
\end{aligned}
$$

$A_{i}$ represents the dependent variable in the model, which was coded as " 1 " if respondents agreed with the implementation of a simplified standard on NFI for SMEs as mandatory and "0" otherwise. By simplification, models 1 to 3 will be mentioned to indicate the regression models, without demographic variables, which include the variables comparability, reliability, and relevance, respectively.

The Omnibus test of model coefficients and the Hosmer and Lemeshow goodness-offit test, presented in Table 5, suggest that all models performed well, indicating that the logistic regression could be used to model the data.

Table 5. Omnibus and Hosmer and Lemeshow tests for the models 1 to 3.

\begin{tabular}{lcccc}
\hline & \multicolumn{2}{c}{ Omnibus Test } & \multicolumn{2}{c}{ Hosmer and Lemeshow Test } \\
\hline \multicolumn{1}{c}{ Model } & Chi-Square & Sig. & Chi-Square & Sig. \\
\hline 1-comparability & 43.466 & 0.000 & 6.554 & 0.477 \\
\hline 2-reliability & 55.861 & 0.000 & 9.920 & 0.193 \\
\hline 3-relevance & 51.931 & 0.000 & 3.351 & 0.851 \\
\hline
\end{tabular}

Models 1 to 3 explain between $18 \%$ and $24 \%$ of the total variation, based on the Nagelkerke $\mathrm{R}^{2}$ value, as presented in Table 6 . The first model had the lowest level, conversely to the second one, which had the highest level, despite being close to the third one.

Table 6. Summary of the models 1 to 3 .

\begin{tabular}{lccc}
\hline \multicolumn{1}{c}{ Model } & Log-Likelihood & Cox \& Snell R & ${\text { Nagelkerke } \mathbf{R}^{\mathbf{2}}}^{\text {2 }}$ \\
\hline 1-comparability & 360.861 & 0.135 & 0.183 \\
\hline 2-reliability & 322.044 & 0.180 & 0.244 \\
\hline 3-relevance & 318.765 & 0.170 & 0.230 \\
\hline
\end{tabular}


According to the data provided in Table 7, the models correctly classified between $66 \%$ to $71 \%$, with the second and third models having the highest percentages $(71 \%$ and $70 \%$, respectively). In all cases, the percentages were higher than the initial classification when the explanatory variables were not introduced into the model. In comparison with the initial classification, the correct percentage increased by between 7 and 11 percentage points.

Table 7. Classification table with the cut-off value of 0.5 for the models 1 to 3 .

\begin{tabular}{|c|c|c|c|c|c|}
\hline & & & \multicolumn{3}{|c|}{ Predicted } \\
\hline \multicolumn{3}{|c|}{ Observed } & \multicolumn{2}{|c|}{ Mandatory } & \multirow{2}{*}{ Correct Percentage } \\
\hline & & & 0 & 1 & \\
\hline \multirow{3}{*}{$\begin{array}{c}\text { Model } 1 \\
\text { (comparability) }\end{array}$} & \multirow{2}{*}{ Mandatory } & 0 & 49 & 73 & 40.2 \\
\hline & & 1 & 28 & 149 & 84.2 \\
\hline & \multicolumn{2}{|c|}{ Global percentage } & & & 66.2 \\
\hline \multirow{3}{*}{$\begin{array}{c}\text { Model } 2 \\
\text { (realiability) }\end{array}$} & \multirow{2}{*}{ Mandatory } & 0 & 54 & 58 & 48.2 \\
\hline & & 1 & 24 & 145 & 85.8 \\
\hline & \multicolumn{2}{|c|}{ Global percentage } & & & 70.8 \\
\hline \multirow{3}{*}{$\begin{array}{c}\text { Model } 3 \\
\text { (relevance) }\end{array}$} & \multirow{2}{*}{ Mandatory } & 0 & 44 & 66 & 40.0 \\
\hline & & 1 & 16 & 149 & 90.3 \\
\hline & \multicolumn{2}{|c|}{ Global percentage } & & & 70.2 \\
\hline
\end{tabular}

Finally, Table 8 presents the results of the logistic regression models performed.

Table 8. Results of logistic regression for the models 1 to 3 .

\begin{tabular}{|c|c|c|c|c|c|c|c|}
\hline & & B & S.E. & Wald & Df & Sig. & $\operatorname{Exp}(B)$ \\
\hline \multirow{10}{*}{$\begin{array}{c}\text { Model } 1 \\
\text { (comparability) }\end{array}$} & Comparability & 1.792 & 0.518 & 11.951 & 1 & 0.001 & 6.000 \\
\hline & Usefulness & 0.548 & 0.449 & 1.488 & 1 & 0.223 & 1.730 \\
\hline & Constraints & 0.471 & 0.321 & 2.155 & 1 & 0.142 & 1.601 \\
\hline & Investors & -0.735 & 0.439 & 2.805 & 1 & 0.094 & 0.480 \\
\hline & Preparers & -0.283 & 0.591 & 0.229 & 1 & 0.632 & 0.753 \\
\hline & Accountants & -0.247 & 0.341 & 0.524 & 1 & 0.469 & 0.781 \\
\hline & CSRs/NGOs & 1.057 & 0.356 & 8.832 & 1 & 0.003 & 2.876 \\
\hline & Academics & -0.209 & 0.324 & 0.418 & 1 & 0.518 & 0.811 \\
\hline & Others & -0.218 & 0.308 & 0.500 & 1 & 0.480 & 0.804 \\
\hline & Constant & -1.449 & 0.838 & 2.992 & 1 & 0.084 & 0.235 \\
\hline \multirow{10}{*}{$\begin{array}{c}\text { Model } 2 \\
\text { (reliability) }\end{array}$} & Reliability & 1.870 & 0.441 & 17.989 & 1 & 0.000 & 6.487 \\
\hline & Usefulness & 0.602 & 0.476 & 1.596 & 1 & 0.207 & 1.825 \\
\hline & Constraints & 0.296 & 0.358 & 0.683 & 1 & 0.409 & 1.344 \\
\hline & Investors & -0.669 & 0.444 & 2.270 & 1 & 0.132 & 0.512 \\
\hline & Preparers & -0.045 & 0.595 & 0.006 & 1 & 0.939 & 0.956 \\
\hline & Accountants & -0.115 & 0.367 & 0.098 & 1 & 0.754 & 0.891 \\
\hline & CSRs/NGOs & 1.230 & 0.384 & 10.243 & 1 & 0.001 & 3.420 \\
\hline & Academics & -0.337 & 0.355 & 0.904 & 1 & 0.342 & 0.714 \\
\hline & Others & -0.285 & 0.345 & 0.686 & 1 & 0.408 & 0.752 \\
\hline & Constant & -1.658 & 0.835 & 3.945 & 1 & 0.047 & 0.190 \\
\hline
\end{tabular}


Table 8. Cont.

\begin{tabular}{|c|c|c|c|c|c|c|c|}
\hline & & B & S.E. & Wald & Df & Sig. & $\operatorname{Exp}(B)$ \\
\hline \multirow{10}{*}{$\begin{array}{c}\text { Model } 3 \\
\text { (relevance) }\end{array}$} & Relevance & 2.015 & 0.463 & 18.973 & 1 & 0.000 & 7.502 \\
\hline & Usefulness & 0.401 & 0.487 & 0.678 & 1 & 0.410 & 1.494 \\
\hline & Constraints & 0.278 & 0.354 & 0.618 & 1 & 0.432 & 1.321 \\
\hline & Investors & -0.541 & 0.451 & 1.441 & 1 & 0.230 & 0.582 \\
\hline & Preparers & -0.436 & 0.649 & 0.452 & 1 & 0.502 & 0.647 \\
\hline & Accountants & -0.010 & 0.353 & 0.001 & 1 & 0.977 & 0.990 \\
\hline & CSRs/NGOs & 1.118 & 0.385 & 8.443 & 1 & 0.004 & 3.059 \\
\hline & Academics & -0.325 & 0.352 & 0.855 & 1 & 0.355 & 0.722 \\
\hline & Others & -0.194 & 0.342 & 0.323 & 1 & 0.570 & 0.823 \\
\hline & Constant & -1.471 & 0.887 & 2.749 & 1 & 0.097 & 0.230 \\
\hline
\end{tabular}

Following this, the next three logistic regression models performed for this research are given as follows:

$$
\begin{aligned}
& \text { Logit }\left(A_{i}\right)=\beta_{1} E U \\
& +\beta_{2} S M E s+\beta_{3} \text { Capital providers }+\beta_{4} \text { Scope }+\beta_{5} \text { Comparability }+\beta_{6} \text { Usefulness } \\
& +\beta_{7} \text { Effectiveness }+\beta_{8} \text { Investors }+\beta_{9} \text { Preparers }+\beta_{10} \text { Accountants }+\beta_{11} \text { CSRs } / \text { NGOs } \\
& +\beta_{12} \text { Academics }+\beta_{12} \text { Others }+\varepsilon \\
& \begin{aligned}
\text { Logit }\left(A_{i}\right)=\beta_{1} E U & +\beta_{2} S M E s+\beta_{3} \text { Capital providers }+\beta_{4} \text { Scope }+\beta_{5} \text { Reliability }+\beta_{6} \text { Usefulness }+\beta_{7} \text { Effectiveness } \\
& +\beta_{8} \text { Investors }+\beta_{9} \text { Preparers }+\beta_{10} \text { Accountants }+\beta_{11} \text { CSRs } / \text { NGOs }+\beta_{12} \text { Academics }+\beta_{13} \text { Others } \\
& +\varepsilon
\end{aligned}
\end{aligned}
$$

$\operatorname{Logit}\left(A_{i}\right)=\beta_{1} E U+\beta_{2} S M E s+\beta_{3}$ Capital providers $+\beta_{4}$ Scope $+\beta_{5}$ Relevance $+\beta_{6}$ Usefulness $+\beta_{7}$ Effectiveness $+\beta_{8}$ Investors $+\beta_{9}$ Preparers $+\beta_{10}$ Accountants $+\beta_{11}$ CSRs $/$ NGOs $+\beta_{12}$ Academics $+\beta_{13}$ Others $+\varepsilon$

Models 4 to 6 can be distinguished from the previous ones only for the inclusion of four demographic variables, namely the country of origin of respondents (EU versus non-EU); if they are or represent entities that are SMEs; if they are capital providers; and, finally, if they are within the scope of the provisions of the NFRD. By simplification, these models can be seen as the regression models, with demographic variables, which included the variables comparability, reliability, and relevance, respectively.

Again, either the Omnibus test of model coefficients or the Hosmer and Lemeshow goodness-of-fit test presented in Table 9 indicated that these further models performed well, and then the logistic regression could be used to model the data.

Table 9. Omnibus and Hosmer and Lemeshow tests for the models 4 to 6 .

\begin{tabular}{lcccc}
\hline & \multicolumn{2}{c}{ Omnibus Test } & \multicolumn{2}{c}{ Hosmer and Lemeshow Test } \\
\hline \multicolumn{1}{c}{ Model } & Chi-Square & Sig. & Chi-Square & Sig. \\
\hline 4-comparability & 46.111 & 0.000 & 4.959 & 0.762 \\
\hline 5-reliability & 46.147 & 0.000 & 7.895 & 0.444 \\
\hline 6-relevance & 41.571 & 0.000 & 7.757 & 0.458 \\
\hline
\end{tabular}

Then, it can be observed in Table 10 that the level of total variation that was explained by these models significantly increased, ranging between $32 \%$ and $36 \%$, according to the Nagelkerke $R^{2}$ value. This also means that the level of differences was reduced regarding the $R^{2}$ amongst these models, in comparison with the models 1 to 3.

Based on the data provided in Table 11, these new models also increased the percentage of correctly classified cases, which had a minimum of $72 \%$ for model 4 and a maximum of $75 \%$ for model 5 . Again, in all cases, the percentages were greater than the initial classification 
when the explanatory variables were not introduced into the model. Notwithstanding, higher levels of differences were found (between 15 and 17 percentage points).

Table 10. Summary of the models 4 to 6 .

\begin{tabular}{lccc}
\hline \multicolumn{1}{c}{ Model } & Log-Likelihood & Cox \& Snell R & ${\text { Nagelkerke } \mathbf{R}^{\mathbf{2}}}^{\mathbf{2}}$ \\
\hline 4-comparability & 166.454 & 0.256 & 0.344 \\
\hline 5-reliability & 157.441 & 0.266 & 0.358 \\
\hline 6-relevance & 164.208 & 0.242 & 0.324 \\
\hline
\end{tabular}

Table 11. Classification table with the cut-off value of 0.5 for the models 4 to 6 .

\begin{tabular}{|c|c|c|c|c|c|}
\hline & & & \multicolumn{3}{|c|}{ Predicted } \\
\hline \multicolumn{3}{|c|}{ Observed } & \multicolumn{2}{|c|}{ Mandatory } & \multirow{2}{*}{ Correct Percentage } \\
\hline & & & 0 & 1 & \\
\hline \multirow{3}{*}{$\begin{array}{c}\text { Model } 4 \\
\text { (comparability) }\end{array}$} & \multirow{2}{*}{ Mandatory } & 0 & 37 & 29 & 56.1 \\
\hline & & 1 & 14 & 76 & 84.4 \\
\hline & \multicolumn{2}{|c|}{ Global percentage } & & & 72.4 \\
\hline \multirow{3}{*}{$\begin{array}{c}\text { Model } 5 \\
\text { (reliability) }\end{array}$} & \multirow{2}{*}{ Mandatory } & 0 & 36 & 28 & 56.3 \\
\hline & & 1 & 10 & 75 & 88.2 \\
\hline & \multicolumn{2}{|c|}{ Global percentage } & & & 74.5 \\
\hline \multirow{3}{*}{$\begin{array}{c}\text { Model } 6 \\
\text { (relevance) }\end{array}$} & \multirow{2}{*}{ Mandatory } & 0 & 40 & 26 & 60.6 \\
\hline & & 1 & 13 & 71 & 84.5 \\
\hline & \multicolumn{2}{|c|}{ Global percentage } & & & 74.0 \\
\hline
\end{tabular}

Finally, Table 12 presents the results of the logistic regression models performed for models 4 to 6 .

Table 12. Results of logistic regression for the models 4 to 6 .

\begin{tabular}{|c|c|c|c|c|c|c|c|}
\hline & & B & S.E. & Wald & Df & Sig. & $\operatorname{Exp}(B)$ \\
\hline \multirow{14}{*}{$\begin{array}{c}\text { Model } 4 \\
\text { (comparability) }\end{array}$} & EU & 0.214 & 0.485 & 0.194 & 1 & 0.660 & 1.238 \\
\hline & SMEs & -0.496 & 0.464 & 1.144 & 1 & 0.285 & 0.609 \\
\hline & Capital providers & 0.838 & 0.499 & 2.819 & 1 & 0.093 & 2.311 \\
\hline & Scope & 0.564 & 0.454 & 1.545 & 1 & 0.214 & 1.758 \\
\hline & Comparability & 2.963 & 0.985 & 9.049 & 1 & 0.003 & 19.361 \\
\hline & Usefulness & 0.786 & 0.742 & 1.122 & 1 & 0.290 & 2.195 \\
\hline & Constraints & 0.772 & 0.512 & 2.275 & 1 & 0.131 & 2.165 \\
\hline & Investors & -2.664 & 0.990 & 7.235 & 1 & 0.007 & 0.070 \\
\hline & Preparers & 0.614 & 0.943 & 0.424 & 1 & 0.515 & 1.848 \\
\hline & Accountants & -0.546 & 0.517 & 1.116 & 1 & 0.291 & 0.579 \\
\hline & CSRs/NGOs & 1.176 & 0.605 & 3.778 & 1 & 0.052 & 3.243 \\
\hline & Academics & -0.178 & 0.528 & 0.114 & 1 & 0.736 & 0.837 \\
\hline & Others & -1.130 & 0.562 & 4.043 & 1 & 0.044 & 0.323 \\
\hline & Constant & -1.666 & 1.424 & 1.369 & 1 & 0.242 & 0.189 \\
\hline
\end{tabular}


Table 12. Cont

\begin{tabular}{|c|c|c|c|c|c|c|c|}
\hline & & B & S.E. & Wald & Df & Sig. & $\operatorname{Exp}(B)$ \\
\hline \multirow{14}{*}{$\begin{array}{c}\text { Model } 5 \\
\text { (reliability) }\end{array}$} & EU & 0.692 & 0.477 & 2.100 & 1 & 0.147 & 1.997 \\
\hline & SMEs & -0.766 & 0.500 & 2.354 & 1 & 0.125 & 0.465 \\
\hline & Capital providers & 0.600 & 0.539 & 1.241 & 1 & 0.265 & 1.822 \\
\hline & Scope & 1.011 & 0.542 & 3.478 & 1 & 0.062 & 2.749 \\
\hline & Reliability & 2.876 & 0.778 & 13.671 & 1 & 0.000 & 17.735 \\
\hline & Usefulness & 0.215 & 0.722 & 0.089 & 1 & 0.765 & 1.240 \\
\hline & Constraints & 0.902 & 0.547 & 2.715 & 1 & 0.099 & 2.464 \\
\hline & Investors & -1.208 & 0.767 & 2.481 & 1 & 0.115 & 0.299 \\
\hline & Preparers & 0.668 & 0.915 & 0.533 & 1 & 0.465 & 1.950 \\
\hline & Accountants & -0.202 & 0.517 & 0.152 & 1 & 0.697 & 0.817 \\
\hline & CSRs/NGOs & 1.211 & 0.598 & 4.103 & 1 & 0.043 & 3.356 \\
\hline & Academics & -0.235 & 0.555 & 0.180 & 1 & 0.672 & 0.790 \\
\hline & Others & -0.646 & 0.570 & 1.284 & 1 & 0.257 & 0.524 \\
\hline & Constant & -3.478 & 1.455 & 5.711 & 1 & 0.017 & 0.031 \\
\hline \multirow{14}{*}{$\begin{array}{c}\text { Model } 6 \\
\text { (relevance) }\end{array}$} & $\mathrm{EU}$ & 0.542 & 0.462 & 1.376 & 1 & 0.241 & 1.719 \\
\hline & SMEs & -1.022 & 0.498 & 4.208 & 1 & 0.040 & 0.360 \\
\hline & Capital providers & 0.266 & 0.510 & 0.272 & 1 & 0.602 & 1.305 \\
\hline & Scope & 0.925 & 0.519 & 3.180 & 1 & 0.075 & 2.521 \\
\hline & Relevance & 2.520 & 0.765 & 10.861 & 1 & 0.001 & 12.425 \\
\hline & Usefulness & 0.194 & 0.724 & 0.072 & 1 & 0.789 & 1.214 \\
\hline & Constraints & 0.827 & 0.540 & 2.342 & 1 & 0.126 & 2.287 \\
\hline & Investors & -1.286 & 0.767 & 2.813 & 1 & 0.094 & 0.276 \\
\hline & Preparers & 0.672 & 0.907 & 0.549 & 1 & 0.459 & 1.958 \\
\hline & Accountants & -0.038 & 0.484 & 0.006 & 1 & 0.937 & 0.962 \\
\hline & CSRs/NGOs & 1.522 & 0.594 & 6.568 & 1 & 0.010 & 4.580 \\
\hline & Academics & -0.591 & 0.537 & 1.210 & 1 & 0.271 & 0.554 \\
\hline & Others & -0.753 & 0.533 & 2.001 & 1 & 0.157 & 0.471 \\
\hline & Constant & -2.889 & 1.429 & 4.090 & 1 & 0.043 & 0.056 \\
\hline
\end{tabular}

The next section provides a discussion of the main results obtained through the data previously presented.

\section{Discussion}

From the descriptive statistics and chi-square tests provided in Table 2, statistically relevant differences were found between the subgroups SMEs vs. non-SMEs, with $27 \%$ of SME entities revealing their agreement with the introduction of an obligatory standard on NFI for SMEs. In contrast, almost half of non-SMEs had the same opinion (49\%).

A higher level of difference could be found between entities within and out of the scope of the provisions of NFRD, with $35 \%$ of entities within the scope assuming their agreement with that question, while $53 \%$ of positive answers could be observed in the opposite group.

At a $10 \%$ of significance level, also the subgroups capital providers versus others expressed a slight disagreement on this topic. More specifically, 56\% of capital providers 
indicated their opinion on the introduction of a simplified, but mandatory, standard for SMEs, which can be compared with $44 \%$ of other entities that expressed the same view.

Finally, no relevant differences regarding the question under assessment were found when respondents from the EU were compared with respondents from countries other than the EU.

As shown in Table 3, the respondents with a positive opinion on questions regarding comparability, reliability, and relevance also agreed with the mandatory implementation of a simplified standard for SMEs, weighting close to or higher than $60 \%$. Conversely, only $15 \%$ or less of respondents with a negative opinion on the questions related to those qualitative characteristics agreed with this issue.

The distinct perspective on this topic was stressed by the chi-square test, which identified a statistically significant difference for these cases. This result is aligned with Boiral and Henri [17] and EFRAG [32], who highlighted the importance of the mandatory nature of NFI to increase the comparability of NFI.

The results also show that the perception about the limited reliability of NFI disclosed, pointed out by Green and Cheng [36] and Van Wensen et al. [35], seemed to influence the opinion that the simplified standard for SMEs should be mandatory.

Finally, the opinion about the lack of relevance of non-mandatory NFI seemed to be associated with the view that the simplified standard for SMEs should be mandatory. This finding is in line with Tang and Zhong [59], Lee and Yeo [60], and Krueger et al. [61], who found a positive effect of mandatory sustainability reporting on the relevance of NFI.

In a lower level, the subgroups within questions 13 and 14 that agreed with the usefulness of a simplified standard for SMEs and the effectiveness of it as a means of limiting the burden on SMEs (constraints), respectively, also presented a higher level of agreement with the mandatory use of a simplified standard for SMEs ( $54 \%$ and $56 \%$, respectively). These figures may be compared with the percentages of $34 \%$ and $41 \%$, respectively, that agreed with the question in the opposite subgroup. The differences for these two cases were identified as statistically significant by the chi-square test, based on a significance level of $1 \%$.

The results are in line with previous research that states that NFI is useful for SMEs, since it is a facilitating factor in accessing financial resources; in enabling companies to accomplish and maintain a competitive advantage [20]; in preventing legal restrictions, sanctions, and accusations from pressure groups [62]; and in the positive economic effect on firm behavior on capital markets and on stakeholders other than investors [3].

Being that NFR requests are centered on large companies, they may not be appropriate to SMEs, which have limited resources and capabilities [32]. As a result, the proposition for developing low-cost tools in this field, which could facilitate both decision making and monitoring, has been made to minimize the effect of the lack of resources that have been identified as one of the main barriers to the implementation of sustainable management by SMEs [65]. Therefore, the results are also consistent with the literature on this topic.

Finally, and based on the information regarding the stakeholders' groups provided in Table 4, CSRs /NGOs and academics represent the stakeholders pointed out as the most relevant for the respondents who also agreed with mandatory use of a simplified standard for SMEs, with $69 \%$ and $69 \%$ of positive answers, respectively. On the other hand, in the cases where the relevance of these stakeholders was not pointed out, less than half of respondents ( $39 \%$ and $46 \%$, respectively) agreed with that issue. The statistically significant differences were also confirmed for these two groups.

Following this, the respondents that indicated the preparers as a relevant stakeholder group presented an expressive level of differences between the subgroups regarding the opinion on the mandatory use of a simplified standard for SMEs. However, an important difference in comparison with the previous stakeholders' groups should be mentioned, which was the higher level of agreement with question 15, where the preparers were considered as non-relevant by respondents: $64 \%$, which may be compared with $44 \%$ of positive answers in the opposite group. Despite that, the chi-square test did not reveal statistically significant differences between these two subgroups. Tables 8 and 12 provide 
the results of the logistic regression, which presents a multivariate analysis of the findings, namely the set of variables that may be seen as relevant for explaining the probability of success for the dependent variable, namely the mandatory use of a simplified standard for SMEs. Having a different perspective, some inconsistencies may arise in comparison with the previous ones.

From Table 8, the results of the logistic regression for the three initial models with no demographic variables were presented. The findings consistently showed a positive and highly significant relationship between the opinion on the mandatory use of a simplified standard on NIF for SMEs and the following set of variables, with coefficients between 1.8 and 2.0: comparability, reliability, and relevance, which were included in models 1, 2, and 3 , respectively.

Then, and with a positive and highly significant relationship as well, the variable related to the stakeholder group of CSRs/NGOs arose, which represented the opinion by respondents on the relevance of including them in the process of developing this standard. In this case, the coefficients were in the range between 1.1 and 1.2. Considering this set of variables related to stakeholders' groups, investors also arose as having a negative relationship but exclusively for model 1 (which included the variable comparability) and at a significance level of $10 \%$.

Finally, the results of the logistic regression models performed for models 4 to 6 were presented in Table 12. As with the previous models 1 to 3, the variables comparability, reliability, and relevance consistently appeared in these new models as having a positive and highly significant relationship with the opinion on the mandatory use of a simplified standard on NIF for SMEs, with higher coefficients (between 2.5 and 3.0).

With a positive and highly significant relationship again, it appears the variable related to the stakeholder group of CSRs/NGOs, having coefficients in the range between 1.2 and 1.5, which means that they are also higher than the ones before. Notwithstanding, the significance level for this variable increased from 0 to $5 \%$ when these models were compared with the previous ones.

The variable investors also remained in model 4 (which included the variable comparability) with a negative relationship and a coefficient of 2.7. As a novelty in this set of variables related to the stakeholders' groups, it may be mentioned that model 6 (which included the variable relevance) also presented this variable as relevant and negatively related with the dependent variable at the same significance level and a coefficient of 1.3. On the other hand, model 4 additionally included the variable others, being also negatively related and having a coefficient of 1.1. However, a significance level of $5 \%$ was found for this latter case.

Regarding model 5 (which included the variable reliability), the con of a simplified standard as a means of limiting the burden on SMEs exclusively appeared as positively and significantly related with the dependent variable. In this context, a significance level of $10 \%$ and a coefficient of 0.9 were identified.

Finally, regarding the demographic variables, which represented the further variables included in these models, in Table 12 the following variables could be seen as relevant for explaining the probability of success for the dependent variable:

1. Capital providers in model 4 (which included the variable comparability), which was positively related, with a significance level of $10 \%$ and a coefficient of 0.8 ;

2. Scope in models 5 and 6 (which included the variable comparability and reliability, respectively), which was positively related, with a significance level of $10 \%$ and a coefficient between 0.8 and 1.0;

3. SMEs in model 6 (which included the variable relevance), which was the only case that was negatively related, with a significance level of $5 \%$ and a coefficient of 1.0.

To sum up, these new models introduced additional elements that were worthwhile to assess, globally improving the model specification. Despite that, the previous findings remained relevant.

The next section presents the main conclusions from this research. 


\section{Conclusions}

This study assessed the view of stakeholders on the mandatory or voluntary use of a simplified non-financial standards for SMEs. Demographic variables, as well as other relevant information proposed by literature, were used to find the explanatory factors that are behind their perspective.

Considering the recent developments on this matter in the EU, it is relevant to assess the stakeholders' perspective on the recent interest in including SMEs in the scope of NFR.

The first findings identified the SMEs, capital providers and the entities within the scope of the NFRD as the relevant demographic variables, despite some inconsistencies also found when the multivariate analyses (logistic regression) were performed.

The logistic regression was then used, as a method that estimates the probability of occurrence of an event, to determine the predictive variables that explain the stakeholders' position on the topic under assessment in this paper.

Based on that, and in an overall perspective, the most consensual findings were observed for the attributed importance to the concepts of comparability, reliability, and relevance, which provided strong support to the first three hypotheses proposed, aligned with the literature on this topic, highlighted in the previous subsection, namely with EFRAG [32], from which the purpose of NFR is to provide comparable, reliable, and relevant information and that overall comparability is only possible when standards are mandatory.

On the other hand, regarding the following variables (usefulness and constraints), which were behind the fourth and fifth hypotheses, the inconsistencies found did not allow them to be corroborated. In what concerns usefulness, some authors [3] argued that in a context of more relational interaction with stakeholders, a NFI standard is less necessary.

Regarding constraints, the lack of resources is not always seen as a deterministic factor for implementing a proactive sustainability report in SMEs $[2,67,68]$.

Finally, the CSRs/NGOs and investors, with positive and negative coefficients, respectively, were identified as the users with the most robust findings from the views of stakeholders on the possible use of a simplified standard of NFI for SMEs, despite some more occasional pieces of evidence for academics and others. Then, hypothesis six could be partially validated. Consequently, users' needs regarding NFR may have different levels of attributed importance from the stakeholders' perspective. Furthermore, it is relevant to stress that the primary users may differ when financial and NFI are compared, which may be evidenced by the role played by investors, commonly identified by literature as primary users of financial information, conversely to the results regarding NFI found in this research. This finding is also aligned with the legitimacy and the stakeholder theories, as disclosures have to focus on all stakeholder's expectations and not only on their shareholders [28,29]. Therefore, the mandatory adoption of an NFR standard for SMEs may respond to their several stakeholders and legitimize these entities actions.

This paper contributes to an understanding of the stakeholders' perspective on the recent interest in including SMEs in the scope of NFR in the EU through a standardization process, namely in what concerns the possible explanatory factors behind the acceptance of a mandatory simplified standard for SMEs, being useful for users, preparers, regulators, and standard-setters. Thereby, these findings are relevant within the process of developing a NFR model applicable to SMEs based on a mandatory standard, providing evidence that regulators and standard-setters should balance the qualitative characteristics of NFI as well as the needs of various stakeholders within this process.

The conclusions for this research were obtained from data gathered exclusively from the answers provided to the EU public consultation. This element represents the main limitation of this study, which cannot be left out. Therefore, they may not be representative of each group of stakeholders under assessment.

At the end of this research, some perspectives can be suggested in terms of their exploration in future research projects. For instance, further analysis could explore other explanatory factors, including different social, economic, and cultural variables, which may 
be useful to explain the differences of opinion on the use of a simplified standard by SMEs as mandatory, either using the same data source or exploring other alternative sources.

Author Contributions: This study was conceptualized, developed, written, and revised by all the authors equally. All authors have read and agreed to the published version of the manuscript.

Funding: The authors gratefully acknowledge financial support from Instituto Politécnico de Lisboa and from FCT-Fundação para a Ciência e Tecnologia (Portugal), national funding through research grant UIDB/04521/2020.

Institutional Review Board Statement: Not applicable.

Informed Consent Statement: Not applicable.

Data Availability Statement: The original dataset used for this research can be found on https://ec. europa.eu/info/law / better-regulation/have-your-say/initiatives/12129-Revision-of-Non-FinancialReporting-Directive/public-consultation_pt (Accessed 15 December 2021).

Conflicts of Interest: The authors declare no conflict of interest.

\section{References}

1. Bartolacci, F.; Caputo, A.; Soverchia, M. Sustainability and financial performance of small and medium sized enterprises: A bibliometric and systematic literature review. Bus. Strategy Environ. 2020, 29, 1297-1309. [CrossRef]

2. Fernandez-Feijoo, B.; Romero, S.; Ruiz, S. Effect of Stakeholders' Pressure on Transparency of Sustainability Reports within the GRI Framework. J. Bus. Ethics 2014, 122, 53-63. [CrossRef]

3. Christensen, H.B.; Hail, L.; Leuz, C. Mandatory CSR and sustainability reporting: Economic analysis and literature review. Rev. Account. Stud. 2021, 26, 1176-1248. [CrossRef]

4. Brundtland, G.H. Report of the World Commission on Environment and Development (WCED): Our Common Future; Oxford University Press: Oxford, UK, 1987; p. 1163.

5. Porter, M.E.; Kramer, M.R. Strategy and society: The link between competitive advantage and corporate social responsibility. Harv. Bus. Rev. 2006, 84, 78-92. [PubMed]

6. European Parliament. Directive 2014/95/EU of the European Parliament and of the Council of 22 October 2014 amending Directive 2013/34/EU as regards disclosure of non-financial and diversity information by certain large undertaking and groups. Off. J. Eur. Union 2014, L330, 1-9.

7. European Parliament. Proposal for a Directive of the European Parliament and of the Council Amending Directive 2013/34/EU, Directive 2004/109/EC, Directive 2006/43/EC and Regulation (EU) No 537/2014, as Regards Corporate Sustainability Reporting. 2021. Available online: https:/ /www.europeansources.info/record/proposal-for-a-directive-amending-directive2013-34-eu-directive-2004-109-ec-directive-2006-43-ec-and-regulation-eu-no-537-2014-as-regards-corporate-sustainabilityreporting/ (accessed on 4 January 2022).

8. Statista. SMEs in Europe. 2021. Available online: https://www.statista.com/topics/8231/smes-in-europe/ (accessed on 4 January 2022).

9. Altman, E.I.; Sabato, G.; Wilson, N. The value of non-financial information in SME risk management. J. Credit. Risk 2010, 6, 95-127. [CrossRef]

10. Koirala, S. SMEs: Key Drivers of Green and Inclusive Growth; OECD Green Growth Pap. 2019-03; OECD: Paris, Italy, 2018.

11. European Commission. SMEs and the Environment in the European Union; Danish Technol. Inst. and PLANET S.A.; European Commission, DG Enterprise and Industry: Brussels, Belgium, 2010; pp. 1-195.

12. Korca, B.; Costa, E.; Farneti, F. From voluntary to mandatory non-financial disclosure following Directive 2014/95/EU: An Italian case study. Account. Eur. 2021, 18, 353-377. [CrossRef]

13. Kiliç, M.; Uyar, A.; Ataman, B. Preparedness for and perception of IFRS for SMEs: Evidence from Turkey. Account. Manag. Inf. Syst. 2014, 13, 492-519.

14. Litjens, R.; Bissessur, S.; Langendijk, H.; Vergoossen, R. How Do Preparers Perceive Costs and Benefits of IFRS for SMEs? Empirical Evidence from the Netherlands. Account. Eur. 2012, 9, 227-250. [CrossRef]

15. Albu, C.N.; Albu, N.; Pali-Pista, S.F.; Gîrbină, M.M.; Selimoglu, S.K.; Kovács, D.M.; Lukács, J.; Mohl, G.; Müllerová, L.; Paseková, M.; et al. Implementation of IFRS for SMEs in Emerging Economies: Stakeholder Perceptions in the Czech Republic, Hungary, Romania and Turkey. J. Int. Financ. Manag. Account. 2013, 24, 140-175. [CrossRef]

16. Uyar, A.; Güngörmüş, A.H. Perceptions and knowledge of accounting professionals on IFRS for SMEs: Evidence from Turkey. Res. Account. Regul. 2013, 25, 77-87. [CrossRef]

17. Boiral, O.; Henri, J.F. Is Sustainability Performance Comparable? A Study of GRI Reports of Mining Organizations. Bus. Soc. 2017, 56, 283-317. [CrossRef]

18. Barker, R.; Eccles, R.G. Should FASB and IASB Be Responsible for Setting Standards for Nonfinancial Information? SSRN Electron. J. 2018. [CrossRef] 
19. Zahid, R.M.A.; Simga-Mugan, C. An Analysis of IFRS and SME-IFRS Adoption Determinants: A Worldwide Study. Emerg. Mark. Financ. Trade 2018, 55, 391-408. [CrossRef]

20. Oduro, S.; Bruno, L.; Maccario, G. Corporate social responsibility (CSR) in SMEs: What we know, what we don't know, and what we should know. J. Small Bus. Entrep. 2021, 1-32. [CrossRef]

21. Ortiz-Martínez, E.; Marín-Hernández, S. European SMEs and non-financial information on sustainability. Int. J. Sustain. Dev. World Ecol. 2021, 29, 112-124. [CrossRef]

22. Roberts, C.; Sian, S. Micro-Entity Financial Reporting: Perspectives of Preparers and Users; Small and Medium Practices Committee, International Federation of Accountants: New York, NY, USA, 2006.

23. Badia, F.; Bracci, E.; Tallaki, M. Quality and Diffusion of Social and Sustainability Reporting in Italian Public Utility Companies. Sustainability 2020, 12, 4525. [CrossRef]

24. Zyznarska-Dworczak, B. Accounting theories towards non-financial reporting. Stud. Ekon. 2018, 356, 157-169.

25. Crossley, R.M.; Elmagrhi, M.H.; Ntim, C.G. Sustainability and legitimacy theory: The case of sustainable social and environmental practices of small and medium-sized enterprises. Bus. Strategy Environ. 2021, 30, 3740-3762. [CrossRef]

26. Cho, C.H.; Patten, D.M. The role of environmental disclosures as tools of legitimacy: A research note. Account. Organ. Soc. 2007, 32, 639-647. [CrossRef]

27. Van der Laan, G.; Van Ees, H.; Van Witteloostuijn, A. Corporate Social and Financial Performance: An Extended Stakeholder Theory, and Empirical Test with Accounting Measures. J. Bus. Ethics 2008, 79, 299-310. [CrossRef]

28. Laplume, A.O.; Sonpar, K.; Litz, R.A. Stakeholder Theory: Reviewing a Theory That Moves Us. J. Manag. 2008, 34, 1152-1189. [CrossRef]

29. Torelli, R.; Balluchi, F.; Furlotti, K. The materiality assessment and stakeholder engagement: A content analysis of sustainability reports. Corp. Soc. Responsib. Environ. Manag. 2020, 27, 470-484. [CrossRef]

30. Rossignoli, F.; Stacchezzini, R.; Lai, A. Integrated reporting and analyst behaviour in diverse institutional settings. Meditari Account. Res. 2021. [CrossRef]

31. Kaya, D.; Koch, M. Countries adoption of the International Financial Reporting Standard for Small and Medium-sized Entities (IFRS for SMEs)_Early empirical evidence. Account. Bus. Res. 2015, 45, 93-120. [CrossRef]

32. EFRAG. Proposals for a Relevant and Dynamic Eu Sustainability Reporting Standard-Setting; European Reporting Lab: Brussels, Belgium, 2021; p. 228.

33. Dragomir, V.D. The disclosure of industrial greenhouse gas emissions: A critical assessment of corporate sustainability reports. J. Clean. Prod. 2012, 29-30, 222-237. [CrossRef]

34. Aureli, S.; Magnaghi, E.; Salvatori, F. The Transposition of the Non-Financial Reporting Directive in the UK, France and Italy. Emerg. Issues Manag. 2020, 1, 48-67. [CrossRef]

35. Van Wensen, K.; Broer, W.; Klein, J.; Knopf, J. The State of Play in Sustainability Reporting in the European Union; The European Union: Maastricht, The Netherlands, 2011.

36. Green, W.J.; Cheng, M.M. Materiality judgments in an integrated reporting setting: The effect of strategic relevance and strategy map. Account. Organ. Soc. 2019, 73, 1-14. [CrossRef]

37. Talbot, D.; Boiral, O. GHG reporting and impression management: An assessment of sustainability reports from the energy sector. J. Bus. Ethics 2018, 147, 367-383. [CrossRef]

38. Brennan, N.; Merkl-Davies, D. Accounting narratives and impression management. In The Routledge Companion to Communication in Accounting; Jack, L., Davison, J., Craig, R., Eds.; Routledge: London, UK, 2013.

39. Hahn, R.; Lülfs, R. Legitimizing Negative Aspects in GRI-Oriented Sustainability Reporting: A Qualitative Analysis of Corporate Disclosure Strategies. J. Bus. Ethics 2014, 123, 401-420. [CrossRef]

40. Ogden, S.; Clarke, J. Customer disclosures, impression management and the construction of legitimacy. Account. Audit. Account. J. 2005, 18, 313-345. [CrossRef]

41. Diouf, D.; Boiral, O. The quality of sustainability reports and impression management: A stakeholder perspective. Account. Audit. Account. J. 2017, 30, 643-667. [CrossRef]

42. Ruiz-Blanco, S.; Romero, S.; Fernandez-Feijoo, B. Green, blue or black, but washing-What company characteristics determine greenwashing? Environ. Dev. Sustain. 2021, 24, 4024-4045. [CrossRef]

43. Venturelli, A.; Pizzi, S.; Leopizzi, R.; Caputo, F.; Adamo, S. Achieving sustainable development goals through non-financial regulation. First insights from the transposition of Directive 95/2014/EU in Italy. Ital. Account. Rev. 2019, 9-12, 91-103.

44. Aureli, S.; Magnaghi, E.; Salvatori, F. The Role of Existing Regulation and Discretion in Harmonising Non-Financial Disclosure. Account. Eur. 2019, 16, 290-312. [CrossRef]

45. Borga, F.; Citterio, A.; Noci, G.; Pizzurno, E. Sustainability report in small enterprises: Case studies in Italian furniture companies. Bus. Strategy Environ. 2009, 18, 162-176. [CrossRef]

46. Pizzi, S.; Venturelli, A.; Caputo, F. The 'comply-or-explain' principle in directive 95/2014/EU. A rhetorical analysis of Italian PIEs. Sustain. Account. Manag. Policy J. 2021, 12, 30-50. [CrossRef]

47. La Torre, M.; Sabelfeld, S.; Blomkvist, M.; Tarquinio, L.; Dumay, J. Harmonising non-financial reporting regulation in Europe: Practical forces and projections for future research. Meditari Account. Res. 2018, 26, 598-621. [CrossRef]

48. Dando, N.; Swift, T. Transparency and Assurance: Minding the Credibility Gap. J. Bus. Ethics 2003, 44, 195-200. [CrossRef]

49. Duchon, D.; Drake, B. Organizational narcissism and virtuous behavior. J. Bus. Ethics 2009, 85, 301-308. [CrossRef] 
50. Deegan, C.; Cooper, B.J.; Shelly, M. An investigation of TBL report assurance statements: UK and European evidence. Manag. Audit. J. 2006, 21, 329-371. [CrossRef]

51. Milne, M.J.; Kearins, K.; Walton, S. Creating Adventures in Wonderland: The Journey Metaphor and Environmental Sustainability. Organization 2006, 13, 801-839. [CrossRef]

52. Johnston, D.M.; Sefcik, S.E.; Soderstrom, N.S. The value relevance of greenhouse gas emissions allowances: An exploratory study in the related united states $\mathrm{SO}_{2}$ market. Eur. Account. Rev. 2008, 17, 747-764. [CrossRef]

53. Bernardi, C.; Stark, A. On the value relevance of information on environmental and social activities and performance-Some evidence from the UK stock market. J. Account. Public Policy 2018, 37, 282-299. [CrossRef]

54. Loh, L.; Thomas, T.; Wang, Y. Sustainability reporting and firm value: Evidence from Singapore-listed companies. Sustainability 2017, 9, 1-12. [CrossRef]

55. Clarkson, P.M.; Fang, X.; Li, Y.; Richardson, G. The relevance of environmental disclosures: Are such disclosures incrementally informative? J. Account. Public Policy 2013, 32, 410-431. [CrossRef]

56. Hassel, L.; Nilsson, H.; Nyquist, S. The value relevance of environmental performance. Eur. Account. Rev. $2005,14,41-61$. [CrossRef]

57. Cardamone, P.; Carnevale, C.; Giunta, F. The value relevance of social reporting: Evidence from listed Italian companies. J. Appl. Account. Res. 2012, 13, 255-269. [CrossRef]

58. Moneva, J.M.; Cuellar, B. The value relevance of financial and non-financial environmental reporting. Environ. Resour. Econ. 2009, 44, 441-456. [CrossRef]

59. Tang, D.Y.; Zhong, R. Mandatory Sustainability Disclosure and Stock Price Crash Risk. 2019. Available online: https: //www.semanticscholar.org/paper/Mandatory-Sustainability-Disclosure-and-Stock-Price-Tang/aca519a27857b52c0ea61ca8 813b3b2c14ee3c15 (accessed on 4 January 2022).

60. Lee, K.-W.; Yeo, G.H.-H. The association between integrated reporting and firm valuation. Rev. Quant. Financ. Account. 2016, 47, 1221-1250. [CrossRef]

61. Krueger, P.; Sautner, Z.; Tang, D.Y.; Zhong, R. The Effects of Mandatory ESG Disclosure around the World; Finance Working Paper No. 754/2021, Swiss Finance Institute Research Paper No. 21-44; European Corporate Governance Institute: Brussels, Belgium, 2021. [CrossRef]

62. Van de Wijs, P.P.; Van der Lugt, C.; Petrovics, D. Carrots E Sticks-Sustainability Reporting Policy: Global Trends in Disclosure as the ESG Agenda Goes Mainstream; European Parliament: Brussels, Belgium, 2020; pp. 1-37.

63. Johnson, M.P.; Schaltegger, S. Two Decades of Sustainability Management Tools for SMEs: How Far Have We Come? J. Small Bus. Manag. 2016, 54, 481-505. [CrossRef]

64. Dinh, T.; Husmann, A.; Melloni, G. The Role of Non-Financial Performance Indicators and Integrated Reporting in Achieving Sustainable Value Creation; European Parliament: Brussels, Belgium, 2021. Available online: https://data.europa.eu/doi/10.2861/783506 (accessed on 4 January 2022).

65. Shields, J.F.; Shelleman, J.M. SME sustainability dashboards: An aid to manage and report performance. J. Small Bus. Strategy 2020, 30, 106-114.

66. Corazza, L. The standardization of down-Streamed Small Business Social Responsibility (SBSR): SMEs and their sustainability reporting practices. Inf. Resour. Manag. J. 2017, 30, 39-52. [CrossRef]

67. Torugsa, N.A.; O'Donohue, W.; Hecker, R. Capabilities, Proactive CSR and Financial Performance in SMEs: Empirical Evidence from an Australian Manufacturing Industry Sector. J. Bus. Ethics 2012, 109, 483-500. [CrossRef]

68. Rodríguez-Gutiérrez, P.; Guerrero-Baena, M.D.; Luque-Vílchez, M.; Castilla-Polo, F. An approach to using the best-worst method for supporting sustainability reporting decision-making in SMEs. J. Environ. Plan. Manag. 2021, 64, 1-24. [CrossRef]

69. Stekelorum, R.; Laguir, I.; Elbaz, J. CSR disclosure and sustainable supplier management: A small to medium-sized enterprises perspective. Appl. Econ. 2018, 50, 5017-5030. [CrossRef]

70. Calace, D. Non-Financial Reporting in Italian SMEs: An Exploratory Study on Strategic and Cultural Motivations. Int. J. Bus. Adm. 2014, 5, 34-48.

71. Altman, E.I.; Sabato, G. Modelling Credit Risk for SMEs: Evidence from the U.S. Market. Abacus 2007, 43, 332-357. [CrossRef]

72. Midi, H.; Sarkar, S.K.; Rana, S. Collinearity diagnostics of binary logistic regression model. J. Interdiscip. Math 2010, 13, $253-267$. [CrossRef]

73. Senaviratna, N.A.M.R.; Cooray, T.M.J.A. Diagnosing Multicollinearity of Logistic Regression Model. Asian J. Probab. Stat. 2019, 5 , 1-9. [CrossRef] 